\title{
Review
}

\section{Europe after Derrida: Crisis and potentiality}

\author{
Agnes Czajka and Bora Isyar (Eds.) \\ Edinburgh University Press, Edinburgh, 2014, ix+170pp., ISBN: 978-0748683369 \\ Contemporary Political Theory (2016) 15, e25-e28. doi:10.1057/cpt.2015.13; \\ published online 10 March 2015
}

Today Europe is mostly associated with having a 'debt crisis' and being unable to manage all sorts of borders regarding its membership. As the European Union (EU) grapples with the economic implications of a common currency and the political and legal constitution of institutions such as a European Parliament and Court of Justice, it has also had to seek ways of managing cultural, ethnic and religious differences by trying to control where the parameters between Europe/ans and non-Europe/ans start and stop. Such problems facing Europe today can be thought of as an identity crisis, or perhaps an identity in deconstruction, which is what interested Jacques Derrida when he speculated on Europe's demarcation and direction from a different juncture of 'today' over 20 years ago. Derrida's The Other Heading: Reflections on Today's Europe, written not long after the fall of the Berlin Wall, the cusp of the Soviet Union's dissolution and the advent of the Maastricht Treaty, provides the point of departure for the 10 essays and introduction assembled in Europe After Derrida: Crisis and Potentiality. This collection offers a timely intervention into debates about Europe that predominantly do not question how the current crises are linked to more fundamental issues regarding the shifting grounds in which various borders demarcating Europe attempt to settle.

As Engin Isin asks in the chapter, 'We, the Non-Europeans: Derrida and Said', '[i]f in fact the crisis of Europe is more fundamental than the current crisis that engulfs it, then how do we diagnose that fundamental crisis?' (p. 108). Each essay affirms Derrida's emphasis on the non-contemporaneity of any present to itself and the difference within any shot at articulating an unified identity as the more fundamental crisis in approaching Europe's current problems. Reflecting on these two inescapable traits of effecting presence and identity, shaping how we understand both history and belonging, is essential for engaging with both the heritage of what is called Europe and the promise of what Europe might become. Highlighting Derrida's neologism, différance - the general economy through which presence and identity pose itself as a problem - the editors underscore that there can be no articulation of any identity without an encounter of what is other to it. Identity acquires its meaning through a play of differences that simultaneously defers the arrival of settling on 'what 
(something) is'. Thus Europe and Europeans acquire their presumed identities only in relation to what is cast as non-Europe and as non-European others, which cannot be temporally and spatially fixed. Yet calls for cultural unity and appeals to a European identity continually obfuscate and fail to recognise irreducible differences of constitutive others that lie at the heart of Europe's origins and many current claims for an essential European identity. This collection provocatively asks, after Derrida, what if the lack of a self-same identity is to be affirmed rather than overcome? What kind of Europe can emerge from this?

Another way of affirming and working with the differences within and outside of the presumption of Europe's self-same identity is to recognise what kind of border projects constitute predominant understandings of it. Such border projects are also invested in relations of power. In 'The Borders of Contemporary Europe: Territory, Justice and Rights', Tracey Skillington focuses on how Europe as a 'territorial entity' and a 'cultural project of belonging' are framed in such a way that the 'territorial privileges and vetoing powers of Europe's self-determining sovereignties' trump the 'universally applicable rights ... to free movement and safe haven or asylum' (p. 95). Citing an European Commission report, Skillington reiterates that Europe 'is not a fact. It is a task and process' (p. 95). As a task that also engages the borders of religious, economic, political and philosophical differences, each of the essays reminds us that the presumed 'essence' of Europe is historical; its representations to itself and what gets carved as non-Europe are contingent and particular rather than unchanging and universal. The mainstream understanding of Europe as birthplace or 'head' of the West has suppressed the particularity of how non-Europe was crucial to its formation. This book considers other shores, other subjects and other headings that have supported Europe's idea of itself.

Gasché's (2007) response to postcolonial critics' work on Europe's others is cited recurrently through the book. Simon Glendinning's 'Derrida's Europe: Greek, Christian and Beyond' deals with Gasché's reflections on philosophy and Europe most explicitly. Europe is generally given credit for the origins of reason and science, the home of the Enlightenment and the head of modernity. But as postcolonial critics point out, the presumed universality of the norms and values associated with this Western 'centre' of the world also provided a justification for the 'civilising missions' of imperialism and colonial conquest in Asia, the Americas, Africa and Oceania. Gasché warns that postcolonial writers too often homogenise their idea of Europe in their criticisms within their own claims that colonised peoples have been unduly homogenised. Glendinning agrees with Gasché's point; one should not reject philosophy outright because of its Eurocentric heritage and complicity with a form of rationality that was used to justify colonialist conquest. But he also argues that Gasché's defence of rationality closes off too quickly the other headings in which taking responsibility for the Graeco-Christian understanding of the world could go. Closer to Derrida's strategy to resist the 'exhausted programs' and traditional conceptuality of choosing between Eurocentrism and anti-Eurocentrism, Glendinning 
emphasises that, in maintaining what is worthy from the European heritage of philosophy, it is also imperative to direct guardianship over the idea of Europe towards an openness that is embroiled in what Europe is not. Other chapters deal more specifically with heading towards specific non-European others and other shores.

The shore to which Derrida had turned himself, connected to his own birthplace in Algeria, was the Mediterranean. Recalling that for centuries, Jews were marked as the internal other of Europe and that many Jews had lived in the Eastern Mediterranean, Sherene Seikaly and Max Ajl - in 'Of Europe: Zionism and the Jewish Other' - trace how Zionism involved the de-orientalising of the Jew in Europe whereby the construction of the Jewish state can be read as the 'becoming European of Jews'. They argue that the Jewish state acted as a shield for Europe on the Mediterranean shore, whose colonising project also erased Jewish cultures of the East (Kurdish, Turkish, Indian and Algerian). Dispossessed from their land, Palestinians became demonised and othered in ways in which Jews had been in Europe. Here it is evident that the internal other to Europe today is not the Jew, but the Arab and/or Muslim. The Muslim as EU's primary internal other is raised in many essays, but is most specifically dealt with in the two charting the conditions of Turkey's membership in the EU.

With a Muslim majority population, Turkey is a good case for analysing how the promoted values of cosmopolitanism and secularism do not work equally on all religions. In 'The European Ideal in the face of the Muslim Other', Zeynep Direk argues that the mix of theologico-politics with technocratic governance in the EU exhibits difficulty in disentangling religion from a secular national identity at the same time in which the state finds it difficult to privatise certain aspects of religious expression and behaviour. Most significantly, the form in which secular national identities are forged within membership to the EU functions in such a way that the purported pluralism and respect for religious difference accords primacy to values and practices that are dominant: those of Christianity. In addition to discussing Turkey's membership within the EU as conditional (particularly in differential treatment regarding trade agreements), Ian Morrison analyses the presence of Muslim migrants within Europe as minority populations in 'Christianity, Secularism and the Crisis in Europe'. Accused of threatening the presumed identity of Europe, Muslim minority populations are treated as a foreign antigen threatening to take over Europe's 'body proper' (expressed as the 'Islamisisation of Europe' and 'Eurabia'). This prompts a reflection on Derrida's discussion of auto-immunisation - a process in which the operation of a living organism's means of self-protection turns against itself.

Autoimmunity alerts readers to the idea that attacking an internalised other - such as Muslim minority populations - is also an attack on what is presumed as the self. For the inability for Europe to recognise the complicity between Europe and non-Europe in its self-constitution is precisely what will compromise the ideals of cosmopolitanism, secularism and the equitable distribution of rights and responsibilities. This relation between self and non-self resonates between all essays in recalling Derrida's approach to Europe as a task that warns against submission to either one of two 
contradictory impulses: to subsume differences in the name of unity and centralise governance in an overly concentrated way, or to yield to embracing differences so loosely that they begin to flourish into 'petty little nationalisms'. There is no magical formula for how to rethink and rework this conundrum, but the commitment to an openness that conceptualises Europe as necessarily and irreducibly heterogeneous and unending might be a start.

Inheriting what has happened in Europe's name then is dependent on what those taking responsibility for Europe today choose to extract from it. Whether written into the constitution or not, Matthias Fritsch in 'Europe's Constitution for the Unborn', argues that the foundations of a tradition only acquire their pledged significance when countersigned by future generations. In various ways, all essays countersign Derrida's promise for Europe to be open to the 'Other Heading' - towards what Stuart McLean in his chapter, 'Other Shores: Insularity, Materiality and the Making (and Unmaking) of "Europe", names as 'the lives and futures that can never be prescriptively ranged under the rubric of a European history and identity' (p. 76). As heirs of this thing called Europe, authors of this book countersign Derrida's promise of hospitality to the 'incursions of alterity' (p. 76), which in turn invite all of us to respond, countersign and take responsibility for what happens in Europe's name 'today'.

\section{Reference}

Gasché, R. (2007) This little thing called Europe. CR: The New Centennial Review 7(2): 1-19.

Carolyn D'Cruz

La Trobe University, Bundoora, Melbourne VIC 3086, Australia c.dcruz@latrobe.edu.au 